\title{
Model of routing for raw milk collection using genetic algorithms
}

Ricardo Rosales Vásquez Universidad Autónoma de Occidente / ricardorosales_v@hotmail.com

Maritza Correa Valencia, Ph.D. Universidad Autónoma de Occidente / mcorrea@uao.edu.co

ABSTRACT The article examines the use of a metaheuristic method - genetic algorithms - for evaluating a model of routes for raw milk collection. A model was implemented based on real data, collected through fieldwork, following the method of the «traveling agent's problem», using the toolbox of Matlab® genetic algorithm. The results show that the routes obtained with the implementation of the genetic algorithm are feasible in terms of time and visited nodes, demonstrating the potential of this tool. The costs obtained by this method differ from the current methods by about $3 \%$, which is within the range reported in the literature.

KEYWORDS Model of routing; metaheuristic methods; genetic algorithms.

Modelo de ruteo para recolección de leche cruda usando algoritmos genéticos

\begin{abstract}
RESUMEN El artículo presenta la utilización de un método metaheurístico - algoritmos genéticos- para la evaluación de un modelo de rutas de recolección de leche cruda. Se implementó un modelo a partir de datos reales, recolectados por medio de trabajo de campo, siguiendo el método del «problema del agente viajero», usando el toolbox de algoritmos genéticos de Matlab ${ }^{\circledR}$. Los resultados evidencian que las rutas obtenidas con la implementación del algoritmo genético son viables en cuanto a tiempo y nodos visitados, lo que demuestra el potencial de esta herramienta. Los costos obtenidos por este método difieren de los actuales en alrededor de $3 \%$, valor que está dentro de los márgenes reportados en la literatura.
\end{abstract}

PALABRAS CLAVE Modelo de ruteo; métodos metaheurísticos; algoritmos genéticos.
Modelo de roteamento para coleta de leite cru utilizando algoritmos genéticos

RESUMO O artigo mostra o uso de um método meta heurístico - algoritmos genéticos - para avaliar um padrão de rotas de coleta de leite cru. Foi implementado um modelo baseado em dados reais, coletados por meio de trabalho de campo, seguindo o método do "Problema do Caixeiro Viajante", usando os algoritmos genéticos da caixa de ferramentas Matlabß. Os resultados mostram que as rotas obtidas com a implementação do algoritmo genético são viáveis em termos de tempo e de nós visitados, demonstrando assim o potencial desta ferramenta. Os custos obtidos por este método diferem dos atuais em aproximadamente $3 \%$, o que está dentro do intervalo referido na literatura.

PALAVRAS-CHAVE Modelo de roteamento; métodos meta heurísticos; algoritmos genéticos. 


\section{Introduction}

The treaties and trade agreements signed by the Colombian government mean that national organizations are constantly searching for improvements, as well as reduction in the costs of their processes, in order to obtain a balance between the needs of the global market and effective responses of organizations. The market growth generated from these trade agreements makes it essential to improve the competitiveness of any company.

The routing system for the collection of raw milk used by the company under study is, in a sense, empirical, which does not guarantee the greatest efficiency and makes essential its evaluation and redesign, a problem that in this research has been addressed through the implementation of the heuristic method of genetic algorithms, a tool with scope in diverse areas such as technology and optimization of manufacturing processes (Larrañaga, Kuijpers, Murga, Inza, \& Dizdarevic, 1999).

The selection of the tool for analysis and redesign of the current model routes of the company concerned is due to the positive results of various studies aimed at solving vehicle routing problems [VRP] using genetic algorithms - e.g., Berger and Barkaoui (2003), Garcia-Najera and Bullinaria (2011), Jozefowiez, Sernet, and Talbi (2009), Lei and Guo (2010), Nagata, Bräysy, and Dullaert (2010), and Vansteenwegen, Souffriau, and Sörensen (2010) - which proved its efficiency to solve different variants of VRP obtaining answers on the order of $1 \%$ in average deviation according to the optimal cost.

As regards VRP applications, Sterzik and Kopfer (2013) report a case study of a company in Germany, focusing on the transport and distribution of vehicles in different regions of the country; Barker and Ayechew (2003) describe several case studies where the application of algorithms related to VRP allowed significant reductions in the costs of distribution and transport; and Alegre, Laguna, and Pacheco (2007) offer a case study related to the collection of materials and raw materials for a manufacturer of automotive parts, in which is chosen a very long time horizon for the selected time.

In the agricultural field, the VRP has been implemented in the programming of transport, both livestock and agricultural products (Oppen \& Lokketangen, 2008; Sigurd, Pisinger, \& Sig, 2004) and has also been applied to food logistics (Tarantilis \& Kiranoudis, 2005).

Coene, Arnout, and Spieksma (2008) report a case

\section{Introducción}

La entrada en vigencia de los tratados y acuerdos comerciales firmados por el Gobierno colombiano enfrenta a las organizaciones nacionales a una constante búsqueda de mejoras, y a la necesidad de reducir los costos de sus procesos, para así obtener el equilibrio entre las necesidades del mercado global y las respuestas efectivas de las organizaciones. El crecimiento del mercado que se genera a partir de estos acuerdos comerciales, hace indispensable mejorar la competitividad de cualquier tipo de empresa.

El sistema de rutas usado por la empresa objeto de estudio para la recolección de leche cruda es, de cierta manera, empírico, lo que no garantiza que sea el más eficiente y hace indispensable su evaluación y rediseño, un problema que en esta investigación se ha abordado mediante la implementación del método heurístico de algoritmos genéticos, una herramienta con campo de aplicación en ámbitos tan dispares como el tecnológico y la optimización de procesos de fabricación (Sierra, 2009).

La selección de la herramienta para el análisis y rediseño del modelo actual de rutas de la empresa citada obedece a los resultados positivos que muestran diversos estudios dirigidos a solucionar problemas de enrutamiento de vehículos [Vehicle Routing Problem, VRP] usando algoritmos genéticos -e.g., Berger y Barkaoui (2003); Garcia-Najera y Bullinaria (2011); Jozefowiez, Sernet, y Talbi (2009); Lei y Guo (2010); Nagata, Bräysy, y Dullaert (2010); y Vansteenwegen, Souffriau, \& Sörensen (2010)- los cuales demostraron su eficiencia para resolver diversas variantes del VRP al obtener respuestas del orden del $1 \%$ en promedio de desviación con respecto del costo óptimo.

Sobre las aplicaciones del VRP: Sterzik y Kopfer (2013) reportan un caso de estudio de una empresa en Alemania, centrado en el transporte y la distribución de vehículos en diversas regiones de ese país; Barker y Ayechew (2003) describen varios casos de estudio donde la aplicación de algoritmos relacionados al VRP permitió importantes reducciones en los costos de distribución y transporte; y Alegre, Laguna, y Pacheco (2007), ofrecen un caso de estudio relacionado con la recolección de materiales y materias primas para un fabricante de piezas de automóviles, en el cual se escoge un tiempo muy largo para el horizonte de tiempo seleccionado.

En el campo agropecuario el VRP se ha implementado en la programación del transporte, tanto de ganado, como de productos agrícolas (Sigurd, Pisinger, \& Sig, 2004; Oppen \& Lokketangen, 2008), y también se ha aplicado a la logística de alimentos (Tarantilis \& Kiranoudis, 2005).

Coene, Arnout, \& Spieksma (2008) reportan un caso de estudio de VRP periódico aplicado a una empresa belga dedicada a la recolección de residuos en los mataderos, carnicerías y supermercados, en el cual la planificación de la ruta se hizo sobre un horizonte temporal de varios días, en los cuales se realiza la visita a clientes que tienen diversas 
frecuencias. Panapinun y Charnsethikul (2005), por su parte, investigaron el caso de una empresa encargada de la distribución de productos perecederos; sus resultados mostraron una reducción de entre el 11 y el $27 \%$ de la distancia total de la ruta inicial de operación, sin incrementos en el costo total del sistema.

En cuanto a trabajos donde es importante tanto el tiempo de recolección, como la asepsia: Claassen y Hendriks (2007) describen un problema de recolección de leche en el que es fundamental que el producto se recoja mientras se encuentra fresco; y Hemmelmayr, Doerner, Hartl, y Savelsbergh (2008) investigaron acerca de la entrega periódica de productos sanguíneos a los hospitales de la Cruz Roja en Austria. Asimismo, Amorim et al., (2012) abordaron el problema de ruteo de vehículos en una empresa portuguesa de distribución de alimentos a diario, específicamente en la asignación eficiente de su flota vehicular para un horizonte temporal medianamente grande utilizando búsqueda local adaptativa, técnica que ha mostrado su eficiencia en otros casos de problemas de enrutamiento de vehículos.

Caramia y Guerreiro (2010) afirman que la recogida de la leche es un problema que es bien conocido en las zonas rurales de todo el mundo; su trabajo se enfoca en un caso similar al tratado en este documento: una empresa láctea que recoge leche cruda de los agricultores en Noruega.

La investigación que da lugar a este artículo se enfocó en el uso de algoritmos genéticos para el rediseño del modelo de ruteo de transporte de una cooperativa lechera de la costa caribe colombiana, con sede en Barranquilla, con el objetivo de encontrar una solución factible para el proceso de recolección de leche cruda, desde los hatos pertenecientes a los ganaderos afiliados a la cooperativa, hasta su planta de procesamiento. El documento está organizado de la siguiente manera: la sección 2 presenta los aspectos teóricos asociados con las metaheurísticas, con énfasis en los algoritmos genéticos; la sección 3 describe la metodología utilizada para abordar el problema; la sección 4 presenta los resultados obtenidos; y la sección 5 resume las conclusiones.

\section{Aspectos teóricos}

\subsection{El problema de enrutamiento de vehículos}

De manera resumida, el problema de enrutamiento de vehículos consiste en poder establecer rutas, al mínimo costo, dados: un conjunto de clientes, unos lugares de almacenamientos diseminados geográficamente y una flota de vehículos, de forma tal que los vehículos inicien y terminen su jornada en lugares de almacenamiento, visitando a los clientes una sola vez. Esta definición sitúa a este problema en un amplio conjunto de variantes.

\subsection{Metaheurísticas y algoritmos}

Glover (1986) define metaheurísticas como un procedimiento maestro de alto nivel que guía y modifica otras heurísticas para explorar soluciones más allá de la simple study of periodic VRP applied to a Belgian company dedicated to the collection of waste in slaughterhouses, butchers, and supermarkets, in which route planning was done on a time horizon of several days, and the visit to customers with different frequencies was performed. Panapinun and Charnsethikul (2005), moreover, investigated the case of a company responsible for the distribution of perishable products; their results showed a reduction between 11 and $27 \%$ of the total distance of the initial route of operation, without increase in the total system cost.

With regard to jobs where it is important both collection time and asepsis, Claassen and Hendriks (2007) describe a problem of milk collection in which it is essential that the product is collected while it is fresh, and Hemmelmayr, Doerner, Hartl, and Savelsbergh (2008) investigate the regular delivery of blood products to the Red Cross hospitals in Austria. Also, Amorim et al. (2012) addressed the problem of vehicle routing in a Portuguese company of daily food distribution, specifically in the efficient allocation of its vehicle fleet to a fairly large time horizon using adaptive local search technique, and which has shown its efficiency in other cases of vehicle routing problems.

Caramia and Guerreiro (2010) state that milk collection is a well-known problem in rural areas throughout the world. Their work focuses on a case similar to that discussed in this paper: a dairy company that collects raw milk from farmers in Norway.

The present paper focuses on the use of genetic algorithms in the redesign of a transport routing model of a dairy cooperative on the Colombian Caribbean coast, headquartered in Barranquilla, with the aim of finding a feasible solution for the raw milk collection process from herds belonging to farming members of the cooperative, and delivery to its processing plant. The paper is organized as follows: section 2 presents the theoretical aspects associated with metaheuristics, with emphasis on genetic algorithms; Section 3 describes the methodology used to address the problem; Section 4 presents the results obtained; and section 5 summarizes the conclusions.

\section{Theoretical Aspects}

\subsection{The vehicle routing problem}

Briefly, the vehicle routing problem requires establishing routes, at minimum cost, given a set of clients, a geographically dispersed storage places, and a fleet of 
vehicles, so that vehicles begin and end their day in storage places, visiting customers once. This definition puts the problem in a wide range of variants.

\subsection{Metaheuristics and algorithms}

Glover (1986) defines metaheuristics as a master high-level procedure that guides and modifies other heuristics to explore solutions beyond the simple local optimality. In general, it can be said that metaheuristics combines ideas from four very different research fields: algorithm design techniques that solve a collection of problems; specific algorithms dependent on the problem to be solved; sources of inspiration from the real world; and statistical methods (Duarte, 2007, p.32). The development of metaheuristics in the last 25 years has contributed to solve problems considered intractable.

Genetic algorithms, well-defined sets of instructions arranged in a way that permits to perform an activity, achieve the resolution of a problem, from a sequence that leads to a solution - algorithms - where the search mechanism imitates a certain natural phenomenon: the evolution of species through genetic inheritance. The main idea of genetic algorithms is to do what nature does (Maroto, Alcaraz, \& Ruiz, 2002). In nature, each species is seeking improvements to achieve adaptation to an environment that is constantly changing.

To Holland (quoted by Laudon \& Laudon, 2004) genetic algorithms - or adaptive computing - refer to various troubleshooting techniques based, conceptually, on the method used by living organisms to adapt to their environment. Therefore, they are scheduled to work the way in which populations solve their problems: changing and reorganizing component parts by processes such as reproduction, mutation, and natural selection. As a consequence, genetic algorithms promote the evolution of solutions to particular problems, controlling the generation, variation, adaptation, and selection of possible solutions through genetically based processes. As solutions are modified and combined, the worst are discarded and the best survive to continue, and even to produce better solutions.

Genetic algorithms are basically distinguished because in each iteration a set of solutions or population and not a single unique solution is obtained; the successors are obtained from pairs formed with the elements of the population and not by transforming the current solution. In summary, the starting point of genetic algorithms is optimalidad local. De modo general, se puede decir que las metaheurísticas combinan ideas que provienen de cuatro campos de investigación bien distintos: técnicas de diseño de algoritmos, que resuelven una colección de problemas; algoritmos específicos, dependientes del problema que se quiere resolver; fuentes de inspiración del mundo real; y métodos estadísticos (Duarte, 2007, p.32). El desarrollo de las metaheurísticas en los últimos 25 años ha contribuido a solucionar problemas que se consideraban inabordables.

Los algoritmos genéticos, conjuntos de instrucciones bien definidas, ordenadas de tal manera que permiten realizar una actividad, lograr la solución de un problema, a partir de una secuencia que lleve a una solución -algoritmos-, cuyos mecanismos de búsqueda imitan un determinado fenómeno natural: la evolución de las especies a través de la herencia genética. La idea principal de los algoritmos genéticos es hacer lo que la naturaleza hace (Maroto, Alcaraz, \& Ruiz, 2002). En la naturaleza, el problema con el que se enfrenta cada especie consiste en la búsqueda de mejoras para conseguir su propia adaptación a un medio que está en constante evolución.

Para Holland (citado por Laudon \& Laudon, 2004) los algoritmos genéticos -o computación adaptativa-, se refieren a varias técnicas de solución de problemas que se basan, conceptualmente, en el método que los organismos vivos usan para adaptarse a su entorno; por tanto, están programados para funcionar de la manera en que las poblaciones resuelven sus problemas: cambiando y reorganizando sus partes componentes mediante procesos como la reproducción, la mutación y la selección natural. En consecuencia, los algoritmos genéticos promueven la evolución de soluciones para problemas particulares, controlando la generación, variación, adaptación y selección de posibles soluciones mediante procesos basados genéticamente. Conforme se modifican y combinan las soluciones, las peores se descartan y las mejores sobreviven para seguir adelante, e incluso, para producir mejores soluciones.

Los algoritmos genéticos se distinguen básicamente porque en cada iteración se obtiene un conjunto de soluciones o población y no una única solución; las sucesoras se obtienen a partir de parejas constituidas con los elementos de la población y no mediante la transformación de la solución en curso. En síntesis, se puede decir que el punto de partida de los algoritmos genéticos es la teoría de la evolución de las especies de Darwin. Si se adopta un procedimiento que dadas dos soluciones genere sucesoras que conserven las mejores características de las mismas, la calidad de las soluciones se mantendrá en las generaciones posteriores (Robusté \& Galván, 2005).

\section{Metodología}

La caracterización del proceso actual se desarrolló bajo la modalidad descriptiva de campo, con la cual se logró identificar las características del proceso de recolección de leche cruda empleado actualmente por la cooperativa. Se 
obtuvo el flujograma del proceso actual, la ubicación de los hatos de los ganaderos afiliados, los centros de acopio y la planta de la cooperativa. Adicionalmente se identificaron las características (tiempos, rutas, vehículos, centros de acopio, cantidad de carga por hato) del proceso actual de recolección.

Una vez hecho el levantamiento de la información, se procedió a implementar el modelo usando el toolbox de algoritmos genéticos de Matlab®, para lo cual se realizó la parametrización del algoritmo en función de un diseño experimental previo, de tal manera que se garantizara su adecuada convergencia.

Inicialmente se trabajó sin definir la cantidad de nodos por ruta, teniendo en cuenta que un solo camión, dada su capacidad, puede visitar a todos los clientes. Esta opción se descartó debido a que genera un incremento no solo en los costos, sino especialmente en los tiempos de recolección por ruta, con relación al modelo actual. Aumentar el tiempo de recolección no es recomendable porque se podrían afectar las características organolépticas de la leche.

Al momento de desarrollar el proyecto se determinó conformar las rutas con el mismo número de nodos visitados por camión, sin que esto afectara la implementación del método metaheurístico seleccionado, para así mantener una base similar a la empleada en la actualidad y así poder seleccionar el modelo que arroje un resultado favorable, en términos de disminución de los costos.

El número de iteraciones (cantidad de clonaciones) requeridas para que el algoritmo genético arroje un resultado fiable, se calculó según la fórmula estadística de muestreo (Ecuación 1).

$$
n=\frac{N *\left(Z_{-} \alpha\right)^{2} * P * Q}{(\delta)^{2} *(N-1)+\left(Z_{-} \alpha\right)^{2} *\left(Z_{-} \alpha\right)^{2}}
$$

Dónde:

$N=$ total de la población (en este caso 51, el número de posibles rutas)

$\left(Z \_\alpha\right)^{2}=1.962$ (con una confianza del 95\%)

$P^{-}=$proporción esperada (en este caso $50 \%$ ) dado

que no se conoce

$$
\begin{array}{ll}
\mathbf{Q} & =1-\boldsymbol{P}(\text { en este caso } 1-0.50) \\
\boldsymbol{\delta} & =\text { precisión }(\text { en este caso se seleccionó el } 5 \%)
\end{array}
$$

Reemplazando los valores se obtuvo que para este problema lo ideal es iterar el algoritmo mínimo 385 veces, con lo cual aumenta la probabilidad de que el resultado sea estadísticamente satisfactorio. Para el rediseño del nuevo modelo se deben tener en cuenta los costos por kilómetro de cada uno de los camiones existentes; estos se calcularon tomando variables como combustible, salarios (ayudante y conductor), peajes, papelería, gastos de mantenimiento, entre otros, con datos conocidos de la organización.

Los costos para la ruta cubierta por uno de los vehículos subcontratados (SNH-072), se calcularon tomando como
Darwin's theory of evolution of species. If a procedure were adopted so that given two solutions it generates successors that preserve their best features, the quality of the solutions will be maintained in subsequent generations (Robusté \& Galván, 2005).

\section{Methodology}

The characterization of the current process was developed under the field descriptive modality with which it was possible to identify the characteristics of the process of collecting raw milk currently used by the cooperative. The flowchart of the current process and the location of herds of the affiliated livestock owners, collection centers, and cooperative plant were obtained. Further characteristics were identified (times, routes, vehicles, collection center, amount of charge per herd) of the current collection process.

Once the collection of the information was done, the model was implemented using the Matlab® toolbox of genetic algorithms, for which the algorithm parameterization was performed according to a previous experimental design, so that adequate convergence could be ensured.

In the beginning it was not defining the number of nodes per route, considering that a single truck, given its capacity, can visit all customers. This option was discarded because it generates an increase not only in costs but especially in times of collection per route, compared with the current model. Increasing the collection time is not recommended because it could affect the organoleptic characteristics of milk.

When developing the project it was determined to draw up the routes with the same number of nodes visited by a truck, without this affecting the implementation of the selected metaheuristic method. This was done in order to maintain a basis similar to that used nowadays so the model which yields a favorable outcome in terms of diminishing costs can be selected.

The number of iterations (number of clones) required for the genetic algorithm to yield a reliable result was calculated according to statistical sampling formula (Equation 1).

$$
n=\frac{N *\left(Z_{-} \alpha\right)^{2} * P * Q}{(\delta)^{2} *(N-1)+\left(Z_{-} \alpha\right)^{2} *\left(Z_{-} \alpha\right)^{2}}
$$


Where:

$N=$ total population (in this case 51 , the possible number of routes)

$\left(Z_{-} \alpha\right)^{2} \quad=1.962$ (with $95 \%$ confidence)

$P \quad=$ expected proportion (in this case $50 \%$ ) because it is unknown

$\mathrm{Q} \quad=1-{ }^{P}$ (in this case $\left.1-0.50\right)$

$\delta=$ accuracy (in this case $5 \%$ was selected)

Replacing values was obtained that for this problem is ideal to iterate the algorithm for at least 385 times, thereby increasing the probability the result is statistically satisfactory. For the redesign of the new model should be taken into account the costs per kilometer of each of the existing trucks; these variables were calculated based on variables as fuel, wages (assistant and driver), tolls, stationery, and maintenance costs, among others, with known data of the organization.

The costs for the route covered by one of the subcontracted vehicles (SNH-072) were calculated based on the value paid off per rent, which included the described expenses applied to other vehicles. Based on these data, the cost per kilometer per truck was calculated, to which was added $4 \%$ foreseeing the possibility of canceling double toll because of road problems (see TABle 1).

The development of this project does not have the capacity of the trucks as a constraint because one of them would be sufficient to meet the current need. In other words, trucks have a large capacity for each of the routes visited (see TABLE 2).

Likewise, it was found that the routes are taken in the morning, although there are no restrictions on visiting hours to each collecting point (A1, B1, C1 ....). However, there is a limit to the number of total hours used in the collection, which must not exceed eight hours.

An identified possible restriction is the capacity of the company's silos for milk storage (Equation 2) - currently 60,000 liters per silo. However, when comparing the information with the cooperative determined that when taking the capacity, the cooperative can call upon other companies located in the city of Barranquilla, as support for product storage. base el valor cancelado por alquiler, el cual incluye los gastos descritos aplicados a los otros vehículos. Con base en estos datos se calculó el costo por kilómetro por cada camión, a lo que se adicionó un 4\% previendo la posibilidad de cancelar doble peaje por problemas viales (ver TABLA $\mathbf{1}$ ).

El desarrollo de este proyecto no cuenta con la capacidad de los camiones como una restricción pues uno solo de ellos bastaría para cubrir la necesidad actual. Es decir, los camiones tienen gran holgura en capacidad para cada una de las rutas visitadas (ver TABLA 2).

De igual forma, se encontró que los recorridos se hacen en horas de la mañana, aunque no existen restricciones en el horario de visita a cada uno de los puntos de captación (A1, B1, C1....). En cambio, si hay un límite en la cantidad de horas totales usadas en la recolección, la cual no debe exceder de 8 horas.

Una posible restricción identificada es la capacidad de los silos para almacenamiento de leche de la empresa (Ecuación 2) -actualmente de 60.000 litros cada uno--. Sin embargo, al contrastar la información con la cooperativa se determinó que al momento de copar la capacidad, la cooperativa puede recurrir a otras empresas del sector ubicadas en la ciudad de Barranquilla, como apoyo para el almacenamiento del producto.

$R 1(X)+R 2(X)+R 3(X)+R 4(X)+L S \leq 120.000$ lts

Dónde, ${ }^{L S}$ corresponde a los litros en stock planta.

\section{Resultados}

Una vez hecho el análisis de las distancias, las restricciones, los costos y las iteraciones mínimas a realizar en el rediseño de las cuatro rutas, se procedió a la implementación del algoritmo genético con el Toolbox de Matlab®, determinando como cromosomas a cada uno de los nodos existentes (51), para así generar iteraciones entre ellos.

Iniciación de la población. Con este método se crea

Table 1. Costs per truck / km / Costos por camión / km

\begin{tabular}{lrrrr}
\hline $\begin{array}{c}\text { License } \\
\text { plate } / \text { Placa }\end{array}$ & $\begin{array}{r}\text { Toll }(\mathbf{4} \%) / \\
\text { Castigo peaje }(4 \%)\end{array}$ & $\begin{array}{r}\text { Total costs } \\
(\$) / \text { Total costos }(\$)\end{array}$ & Total $(\mathbf{k m})$ & $\begin{array}{r}\text { Cost/km } \\
/ \text { Costo } / \text { km }\end{array}$ \\
\hline RDG-233 & $\$ 10.823$ & $\$ 247.926$ & 210 & $\$ 1.181$ \\
SDQ-294 & $\$ 10.063$ & $\$ 259.308$ & 146,95 & $\$ 1.765$ \\
QGD-061 & $\$ 8.444$ & $\$ 216.404$ & 195,54 & $\$ 1.107$ \\
SNH-072 & $\$ 11.200$ & $\$ 291.200$ & 247,8 & $\$ 1.175$ \\
\hline
\end{tabular}

Table 2. Capacity of the trucks / Capacidad de los camiones

\begin{tabular}{llr}
\hline Routes / Rutas & $\begin{array}{l}\text { License plate / } \\
\text { Placa }\end{array}$ & $\begin{array}{r}\text { Capacity (liters) / } \\
\text { Capacidad (litros) }\end{array}$ \\
\hline Route 1 (R1) / Ruta 1 (R1) & RDG-233 & 7.845 \\
Route 2 (R2) / Ruta 2 (R2) & SNH-072 & 12.300 \\
Route 3 (R3) / Ruta 3 (R3) & QGD-061 & 4.000 \\
Route 4 (R4) / Ruta 4 (R4) & SDQ-294 & 8.680 \\
\hline
\end{tabular}


un conjunto de potenciales soluciones, para el caso del agente viajero, combinaciones de recorridos entre ciudades. En este caso seleccionar nodos al azar entre los 51 posibles.

Codificación. Consiste en asignarle un valor o código a cada gen que va a ser usado en el programa.

Gromosoma. Teniendo en cuenta que para este trabajo se conocen las distancias reales entre cada uno de los nodos, se procedió a cargar la variable global de la matriz de $51 \times 51$ donde se cruzaron todos los nodos entre sí. Es necesario aclarar que se adicionó la distancia entre la planta y el nodo inicial de cada ruta y entre el nodo final y la planta. Adicionalmente, se generó una matriz de distancia de $51 \mathrm{x}$ 2 donde se determinó la distancia desde cada uno de los 51 nodos a la planta.

\begin{tabular}{lllllllllll}
\hline A1 & B1 & G1 & D1 & E1 & F1 & G1 & $\ldots$ & P4 & & Ciudades \\
1 & 2 & 3 & 4 & 5 & 6 & 7 & $\ldots$ & 51 & & Genes \\
\hline
\end{tabular}

Ejemplo de la aplicación: Individuos (posible solución)

[25 39404145483543383744463623241424749 5029272625191820431305128323334141516 212217101311129768 ]

Función objetivo. Se busca aplicar una función de aptitud a cada cromosoma - para saber qué tan apto es-, y para conocer la oportunidad de reproducción que tiene cada cromosoma con respecto del resto de la población. Existe una matriz donde se guardan los puntajes totales (scores) de cada cromosoma y su posición dentro de la matriz inicial de población. Dos hijos donde se combinan las características de ambos cromosomas padres.

De igual forma, se consideró el fitness para cada una de las rutas, el cual corresponde a los kilómetros por recorrer partiendo y terminando el recorrido en la planta. El fitness total se calcula sumando fitness de las cuatro rutas.

Selección. Después de conocer la aptitud de cada cromosoma, se seleccionan aquellos con mejor aptitud, los cuales serán cruzados en la siguiente generación.

Gruce. Los dos individuos seleccionados se guardan en una matriz de padres (parents) para su posterior cruzamiento. Para poder calcular los costos de las rutas, inicialmente se determinó el número de nodos a visitar por cada camión y de esta forma, al momento de identificar el fitness para cada uno, se le multiplicó el valor del costo/kilómetro, disponible en la TABLA 1.

Una vez ejecutado el algoritmo genético se obtiene la distribución de la población (nodos) de acuerdo con las distancias y la interacción entre ellos, tal como muestra la Figura 1. Se observan los 51 nodos y el cruzamiento que se generó encaminado a obtener las cuatro rutas con mejor fitness después de las 385 iteraciones.

De igual manera el software brinda el costo de ejecutar estas rutas -en este caso, $\$ 1^{\prime} 049.174,90$, como se muestra en la imagen 2-. Las rutas propuestas son las que muestra la Figura 3.
$R 1(X)+R 2(X)+R 3(X)+R 4(X)+L S \leq 120.000$ lts

Where, ${ }^{L S}$ corresponds to the stock liters in plant.

\section{Results}

Once the analysis of distances, restrictions, costs, and minimum iterations to make the redesign of the four routes was done, the genetic algorithm was implemented with the Matlab® Toolbox, determining as chromosomes to each existing node (51), in order to generate iterations between them.

Initiation of the population. With this method a set of potential solutions is created for the case of a traveling salesman, combinations of routes between cities. Nodes were selected at random from the 51 possible.

Coding. Consists of assigning a value or code to each gene that will be used in the program.

Chromosome. Taking into account that in this work the actual distances between each of the nodes are known, the global variable of matrix of 51 x 51 was loaded, where all the nodes had crossed with each other. It is necessary to note that the distance between the plant and the initial node of each route and the distance between the end node and the plant were added. Additionally, a distance matrix of $51 \times 2$, where the distance was determined from each of the 51 nodes to the plant, was generated.

\begin{tabular}{lllllllllll}
\hline A1 & B1 & G1 & D1 & E1 & F1 & G1 & $\ldots$ & P4 & & Cities \\
1 & 2 & 3 & 4 & 5 & 6 & 7 & $\ldots$ & 51 & & Genes \\
\hline
\end{tabular}

Example of application: Individuals (possible solution)

[25 394041454835433837444636232414247 49502927262519182043130512832333414 1516212217101311129768 ]

Objective function. The objective was to implement a fitness function to each chromosome - to determine how apt it was - and to know the opportunity of reproduction of each chromosome with respect to the rest of the population. There is a matrix where the total scores of each chromosome and its position in the population initial matrix are stored. Two children with the characteristics of both parents' chromosomes were combined.

Likewise, the fitness for each of the routes, which corresponds to the number of kilometers from the start to the end of the route at the plant, was considered. Total fitness was calculated by adding the fitness of the four routes.

Selection. After the aptitude of each chromoso- 

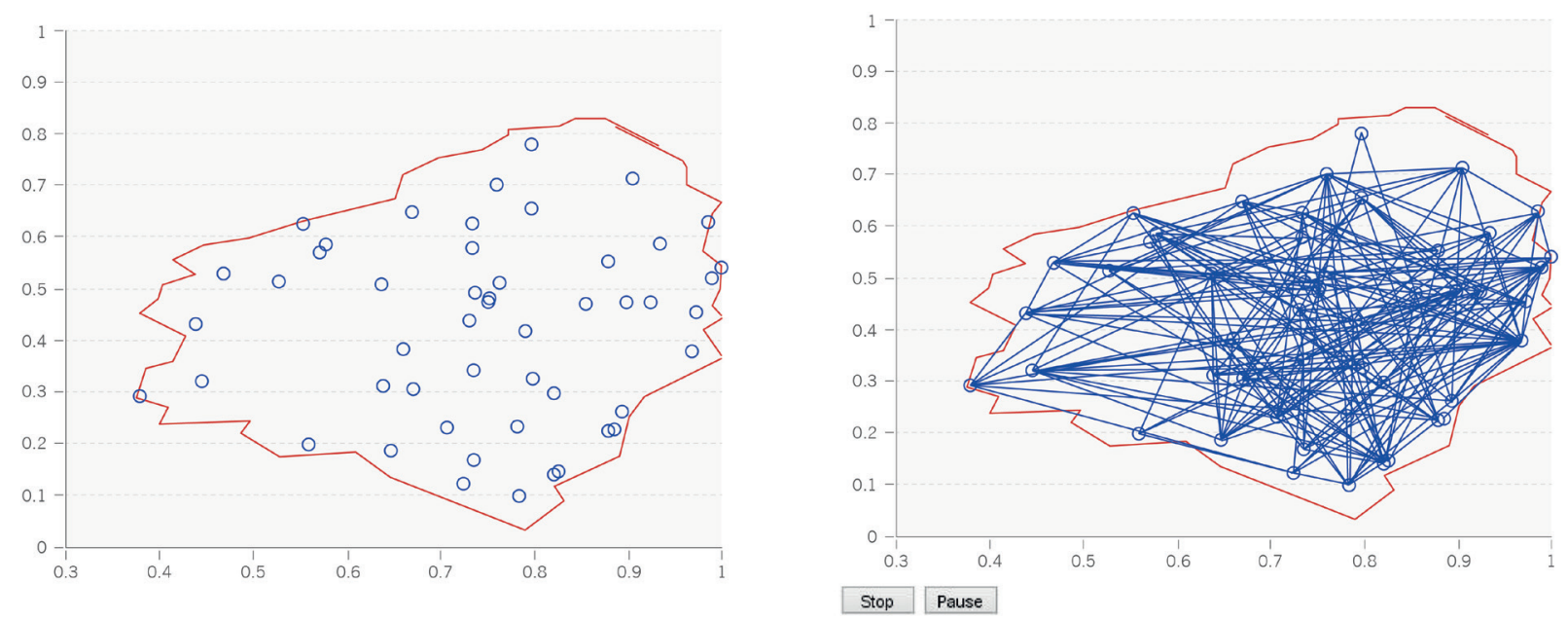

Figure 1. Nodes and crossings / Nodos y cruces

me was known, those with best aptitude were selected, which would be crossed in the next generation.

Crossing. The selected two individuals were stored in a parent's matrix for further crossing. To calculate the costs of routes, initially, the number of nodes to visit for each truck was determined and thus, when identifying the fitness for each, the value of the cost $/ \mathrm{km}$ was multiplied to it (see TABLE 1).

Once the genetic algorithm was executed the population distribution (nodes) in accordance with the distances and the interaction between them was obtained, as shown in Figure 1. The 51 nodes were observed and the crossing that was generated aimed to obtain the four routes with best fitness after 385 iterations.

In a similar vein, the software provides the cost of executing these routes - in this case, $\$ 1^{\prime} 049.174,90$, as shown in image 2. The proposed routes are those shown in Figure 3.

The details of the individuals inside each route and the sequence in which they must be visited appears in each outcome.

Having performed the implementation of the genetic algorithm, it was verified that the model of routing used by the company had greater favorability in terms of operating costs. This is one of the goals:
Route 1 / Ruta 1
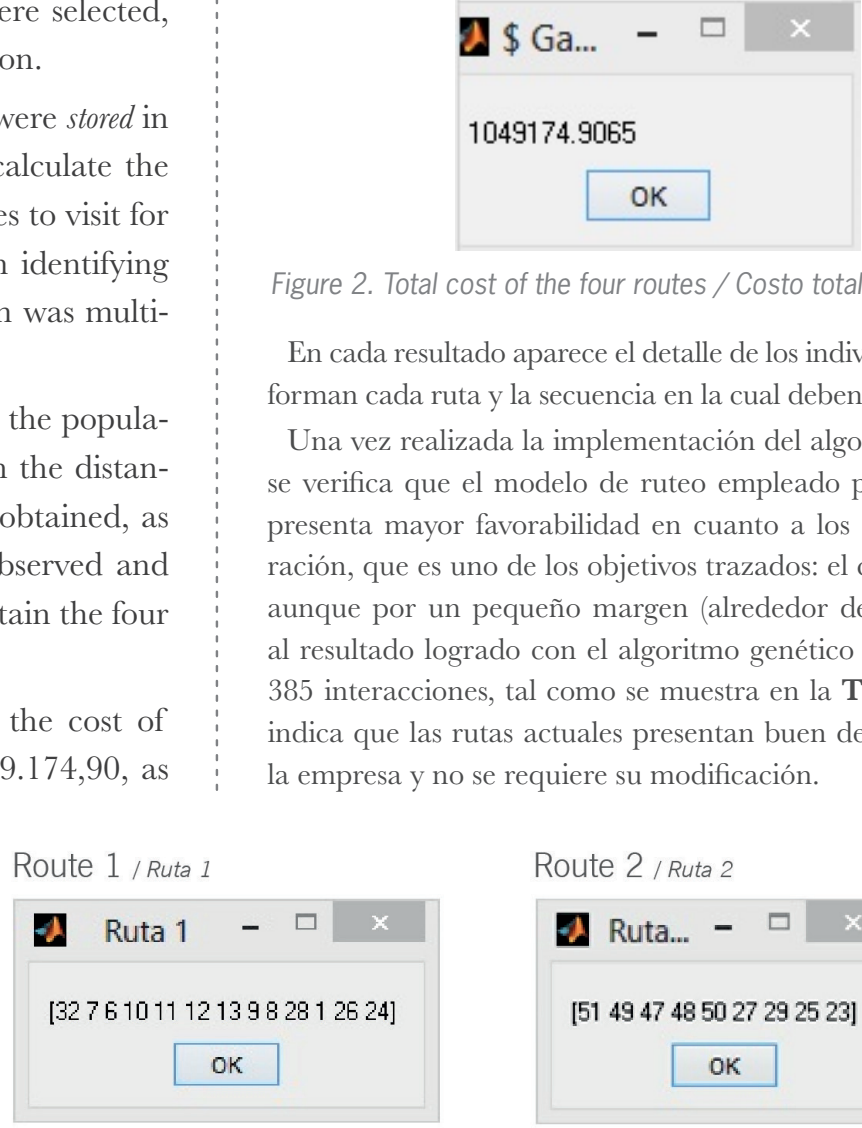

Figure 2. Total cost of the four routes / Costo total por las 4 rutas

En cada resultado aparece el detalle de los individuos que conforman cada ruta y la secuencia en la cual deben ser visitados.

Una vez realizada la implementación del algoritmo genético se verifica que el modelo de ruteo empleado por la empresa presenta mayor favorabilidad en cuanto a los costos de operación, que es uno de los objetivos trazados: el costo actual es, aunque por un pequeño margen (alrededor de 3\%), inferior al resultado logrado con el algoritmo genético después de las 385 interacciones, tal como se muestra en la TABLA 3, lo que indica que las rutas actuales presentan buen desempeño para la empresa y no se requiere su modificación.

Route 2 / Ruta 2

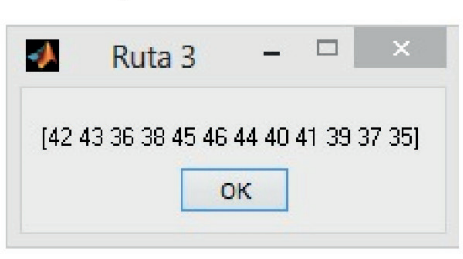

Figure 3. Genetic algorithm vs. current situation / Rutas propuestas luego de ejecutar el algoritmo genético 
Table 3. Capacity of the trucks / Capacidad de los camiones

\begin{tabular}{lr}
\hline Method / Método & Total cost (\$) / Costo Total (\$) \\
\hline Genetic / Genético & $1.049 .085,17 *$ \\
Current / Actual & $1.013 .279,55$ \\
\hline
\end{tabular}

\section{Conclusiones}

El resultado obtenido con la metaheurística algoritmos genéticos para el problema de ruteo de vehículos permite concluir que la implementación de este método es estadísticamente confiable ante diferentes situaciones problemáticas reales en un modelo de ruteo. Asimismo, se estableció que el método tiene gran potencial como herramienta para el establecimiento de rutas, ya que los costos obtenidos difieren solamente en alrededor de $3 \%$ de los actuales.

Se identificó que la capacidad de los camiones se encuentra sobredimensionada con relación a la demanda de los nodos a visitar, debido a que un solo camión cuenta con la capacidad suficiente para realizar la totalidad de las visitas. Sin embargo ajustar el número de vehículo no parece una alternativa factible debido a que las rutas serian demasiado extensas para un producto altamente perecedero, como la leche.

Por medio del modelo diseñado para la recolección de leche cruda en hatos ubicados en el departamento del Atlántico se pudo determinar que el modelo de ruteo actual, pese a ser empírico, es favorable en cuanto a tiempo de recolección y costos, así sea por un pequeño margen, frente a los resultados presentados por el algoritmo genético. SAT the current cost is, although by a small margin (about $3 \%)$, lower than the result achieved with the genetic algorithm after 385 interactions, as shown in TABLE 3, indicating that the current routes have good performance for the company and its modification is not required.

\section{Conclusions}

The result obtained with the metaheuristic genetic algorithms for vehicle routing problem permits to conclude that the implementation of this method is statistically reliable in different real problematic situations in a model of routing. It was also demonstrated that the method has great potential as a tool for establishing routes, since the costs obtained differ by only about $3 \%$ of current costs.

It was found that the truck capacity is oversized in relation to the demand of the nodes to visit, because a single truck has sufficient capacity to carry out all the visits. However, adjusting the number of vehicles does not seem a feasible alternative because the routes would be too extensive for a highly perishable product like milk.

Through the model designed for the collection of raw milk in herds located in the department of Atlántico it was determined that the current model of routing, despite being empirical, is favorable in terms of collection time and costs, even though for a small margin, compared with the results presented by the genetic algorithm. $\mathbf{S T}$

\section{References / Referencias}

Alegre, J., Laguna, M., \& Pacheco, J. (2007). Optimizing the periodic pick-up of raw materials for a manufacturer of auto parts. European Journal of Operational Research, 179(3), 736-746.

Baker, B. M., \& Ayechew, M.A. (2003). A genetic algorithm for the vehicle routing problem. Computers \& Operations Research, 30(5) 787-800.

Berger, J., \& Barkaoui, M. (2003). A new hybrid genetic algorithm for the capacitated vehicle routing problem. The Journal of the Operational Research Society, 54(12), 1254-1262.

Claassen, G. D. \& Hendriks, T.B. (2007). An application of special ordered sets to a periodic milk collection problem. European Journal of Operational Research, 180(2), 754-769.

Coene, S., Arnout, A., \& Spieksma, F. (2008). The periodic vehicle routing problem: a case study [working paper]. Retrieved from http://www.econ.kuleuven.be/public/n05012/

Duarte, A. (2007). Metaheurísticas. Madrid: Dykinson.

García-Najera, A. \& Bullinaria, J. (2011). An improved multi-objective evolutionary algorithm for the vehicle routing problem with time windows. Computers \& Operations Research, 38(1), 287.

Hemmelmayr, V., Doerner, K.F., Hartl, R.F., \& Savelsbergh, M.W. (2009). Delivery strategies for blood products supplies. OR spectrum, 31(4), 707-725.

Jozefowiez, N., Sernet, F., \& Talbi, E.-G. (2009). An evolutionary algorithm for the vehicle routing problem with route balancing. European Journal of Operational Research, 195(3), 761-769.

Larrañaga, P., Kuijpers, C.M.H., Murga, R.H., Inza, I., \& Dizdarevic, S. (1999). Genetic algorithms for the travelling salesman problem: A review of representations and operators. Artificial Intelligence Review, 13(2), 129-170.

Laudon, K.C., \& Laudon, J.P. (2004). Sistemas de información gerencial: administración de la empresa digital. (trans. A. Núñez). México DF: Pearson. 
Lei, H.-T. \& Guo, B. (2010). Comments on "An improved model for vehicle routing problem with time constraint based on genetic algorithm". Computers \& Industrial Engineering, 59(3), 479-480.

Maroto, C., Alcaraz, J., \& Ruiz, R. (2002). Investigación operativa: modelos y técnicas de optimización. Valencia: Universidad Politécnica de Valencia.

Nagata, Y., Bräysy, O., \& Dullaert, W. (2010). A penalty-based edge assembly memetic algorithm for the vehicle routing problem with time windows. Computers \& Operations Research, 37(4), 724-737.

Oppen, J. \& Lokketangen, A. (2008). A tabu search approach for the livestock collection problem. Computers \& Operations Research, 35(10), 3213-3229.

Panapinun, K. \& Charnsethikul, P. (2005). Vehicle routing and scheduling problems: A case study of food distribution in greater Bangkok [working paper]. Retrieved from http://ieinter.eng.ku.ac.th/research/optimization/pan04a.pdf

Robusté, F. \& Galván, D. (2005). e-logistics. Barcelona: Universidad Politécnica de Catalunya.

Sigurd, M., Pisinger, D., \& Sig, M. (2004). Scheduling transportation of live animals. Transportation Science, 38(2), 197-209.

Sterzik, S. \& Kopfer, H. (2013). A tabu search heuristic for the inland container transportation problem. Computers and Operations Research, 40(4), 953-962.

Tarantilis, C. D., \& Kiranoudis, C. T. (2005). Operational research and food logistics. Journal of Food Engineering, 70(3), 253-255.

Vansteenwegen, P., Souffriau, W., \& Sörensen, K. (2010). Solving the mobile mapping van problem: A hybrid metaheuristic for capacitated ARC routing with soft time windows. Computers and Operations Research, 37(11), 1870-1876. 


\section{CURRICULUM VITAE}

Ricardo Rosales Business administrator, master's student of Integral Logistics at the Universidad Autónoma de Occidente (Cali, Colombia).

Maritza Correa Valencia Industrial Engineer, Master in Information technologies applied to production and Doctor of Computer Sciences and Artificial intelligence. Full-time professor and researcher of the Operations and Computer Department at the Universidad Autónoma de Occidente (Cali, Colombia). 